\title{
Baltar, Rosalía (2012): Letrados en tiempos de Rosas. Mar del Plata: EUDEM; 250 pp.
}

Volver la mirada hacia el pasado, desde un lugar innovador, no es tarea senci1la. Sin embargo, en este libro, Rosalía Baltar salva ese desafío con creces.

El abordaje de un período polémico -el rosismo en la Argentina decimonónica-y, al mismo tiempo, excesivamente fosilizado por la historiografía oficial, demanda una aguda exploración de textos que la autora realiza con soltura. Un trabajo de relevamiento y revisión de lugares comunes que permite comprender ese complejo momento desde una perspectiva sagaz:

La lectura de la Historia de la literatura argentina [de Ricardo Rojas] me sugirió la pregunta inicial porque, al llegar al período de que me ocupo en estas líneas, el tomo de Rojas se llama «Los proscriptos». La literatura nacional había corrido su escenario: sus actores y tramoyistas estaban fuera, y las escenas representaban el desierto de la palabra del lado de acá; sólo quedaba alojado lo peor, aquella labilidad de la prensa adicta al régimen, y nada más. Entonces pensé en la posibilidad de que hubiera algo distinto de este lado (p.15).

El libro en cuestión se centra en las diversas configuraciones que delinean el carácter del letrado -intelectual- durante la primera mitad del siglo XIX. Por lo tanto, el trabajo de crítica escrituraria deviene en procedimiento nodal. Asimismo, este proceso de revisión es exhaustivo; ya que abarca desde el análisis de procedimientos y recursos discursivos hasta la dilucidación sociolingüística.

Como punto de partida, el estudio de Rosalía Baltar profundiza en las condiciones particulares del letrado europeo instalado en las riberas del Río de la Plata, a instancias del gobierno de Bernardino Rivadavia. Desde esa específica situación, se relevan los contratiempos y dificultades del quehacer de los intelectuales en el siglo XIX: dilación en las comunicaciones, penurias económicas, dificultades de adaptación e integración. En el inestable marco político de la Argentina durante los primeros decenios decimonónicos, el grupo de "letrados rivadavianos" se erige como la vertiente intelectual que se conforma "del lado de acá", y luego, en confrontación con "los proscriptos". Asimismo, se constituyen como una figura híbrida. No sólo por su extranjería -siempre problemática o problematizada-, sino por la peculiar coyuntura que presenta 
esta época de transición. Desde su formación neoclásica, estos emigrados europeos se ubicarán en un espacio de inestabilidad institucional, donde progresivamente se cuela el romanticismo en ciernes. De tal modo, Baltar releva los cruces y mixturas que se producen entre ambas modalidades estéticas en las figuras de estos letrados, pese a su declarado antirromanticismo. El estudio de su - recientemente editada- correspondencia privada, le permite a la autora rescatar estas tensiones subyacentes.

$\mathrm{Si}$, como señala Baltar, "la historia es, ante todo, versión", la época que abarca el gobierno de Juan Manuel de Rosas en la Argentina emerge como el paradigma de esa observación. Cristalizada como "dictadura" por la historiografía oficial que se impondrá hacia 1880; su figura intelectual clave, Pedro de Angelis, será blanco del olvido y la denostación que le caben en tanto que "letrado rosista”. En su trabajo de indagación, la autora rescata la prolífica producción de este "erudito" italiano, a partir de un perspicaz análisis de su obra pública y su correspondencia privada. Como corolario, la figura de de Angelis se nos muestra en toda su riqueza, lejos de la estigmatización -cargada de xenofobia y elitismo- de la que fuera objeto.

Baltar se ocupa de de Angelis en tanto que "único letrado del rosismo", distinguiéndolo de otros escritores rosistas populares, con los que también, aunque sutilmente, discrepó. Sus trabajos de coleccionista, historiador, editor y periodista, así como las polémicas que arrostró ponen en entredicho el supuesto vacío cultural de ese período. Del mismo modo, el análisis de la autora permite dilucidar el carácter ilustrado y "cortesano" - propio de su formación neoclásica- en la relación peculiar que de Angelis establece con el desacreditado poder del gobernador Rosas.

En ese punto, la figura del "letrado romántico" emerge como contracara, detractor e innegable opositor, encarnada por el escritor Esteban Echeverría. La polémica de Angelis - Echeverría, tópico de la -de por sí polémica y polemizada - literatura argentina, se indaga en profundidad en el libro de Baltar. Del mismo modo, el recorrido minucioso y el análisis metódico de los textos se extienden a otras confrontaciones escriturales de ese período histórico, ilustrando el uso de la "violencia simbólica".

Tras su aguda lectura, junto a los documentados puntos de disenso, la autora señala los inquietantes encuentros; la homología procedimental, la comunidad de estrategias, en fin, la específica construcción de identidades a partir del agónico vínculo discursivo con el otro. 
La primera parte del siglo XIX forjó una imagen de la literatura [argentina] que, más allá de la historia ya oficializada es portadora de una dinámica propia que permite leer las diferencias y revisar los mitos de unidad y de sujetos y, en especial, de verdades que se consolidaron. [...] Nada menos vacío que el Buenos Aires federal, entonces, donde corrían, propiamente, ríos de sangre y de tinta (p.220).

Esta reconstrucción revisada del período rosista es llevada a cabo por Baltar de manera profunda. A esto se suma su estilo grato, no exento de ingeniosa ironía, que hacen de la lectura de su libro una exploración alumbradora.

Vanina Edith Rodríguez

Universidad Nacional de Mar del Plata 